Article

\title{
Fine Regulation of Neutrophil Oxidative Status and Apoptosis by Ceruloplasmin and Its Derivatives
}

\author{
Ekaterina A. Golenkina ${ }^{1}$, Galina M. Viryasova ${ }^{1}$, Svetlana I. Galkina ${ }^{1}$, Tatjana V. Gaponova ${ }^{2}$, \\ Galina F. Sud'ina 1,* (D) and Alexey V. Sokolov $3,4,5$ \\ 1 Belozersky Institute of Physico-Chemical Biology, Lomonosov Moscow State University, Moscow 119234, \\ Russia; golyesha@mail.ru (E.A.G.); gali-inimitable@yandex.ru (G.M.V.); galkina@genebee.msu.su (S.I.G.) \\ 2 FGBU Hematology Research Centre, Russia Federation Ministry of Public Health, Moscow 125167, Russia; \\ gaponova.tatj@yandex.ru \\ 3 FSBSI Institute of Experimental Medicine, St. Petersburg 197376, Russia; biochemsokolov@gmail.com \\ 4 Department of Fundamental Problems of Medicine and Medical Technology, Saint-Petersburg State \\ University, St. Petersburg 199034, Russia \\ 5 Centre of Preclinical Translational Research, Almazov National Medical Research Centre, \\ Saint-Petersburg 197371, Russia \\ * Correspondence: sudina@genebee.msu.ru; Tel.: +7-495-939-5359; Fax: +7-495-939-3181
}

Received: 7 December 2017; Accepted: 10 January 2018; Published: 12 January 2018

\begin{abstract}
Timely neutrophil apoptosis is an essential part of the resolution phase of acute inflammation. Ceruloplasmin, an acute-phase protein, which is the predominant copper-carrying protein in the blood, has been suggested to have a marked effect on neutrophil life span. The present work is a comparative study on the effects of intact holo-ceruloplasmin, its copper-free (apo-) and partially proteolyzed forms, and synthetic free peptides RPYLKVFNPR (883-892) and RRPYLKVFNPRR (882-893) on polymorphonuclear leukocyte (PMNL, neutrophil) oxidant status and apoptosis. The most pronounced effect on both investigated parameters was found with copper-containing samples, namely, intact and proteolyzed proteins. Both effectively reduced spontaneous and tumor necrosis factor- $\alpha(\mathrm{TNF}-\alpha)$-induced extracellular and intracellular accumulation of superoxide radicals, but induced a sharp increase in the oxidation of intracellular $2^{\prime}, 7^{\prime}$-dichlorofluorescein upon short exposure. Therefore, intact and proteolyzed ceruloplasmin have both anti- and pro-oxidant effects on PMNLs wherein the latter effect is diminished by TNF- $\alpha$ and lactoferrin. Additionally, all compounds investigated were determined to be inhibitors of delayed spontaneous apoptosis. Intact enzyme retained its pro-survival activity, whereas proteolytic degradation converts ceruloplasmin from a mild inhibitor to a potent activator of TNF- $\alpha$-induced neutrophil apoptosis.
\end{abstract}

Keywords: apoptosis; neutrophil; ceruloplasmin; superoxide; reactive oxygen species

\section{Introduction}

Human ceruloplasmin $\left(\mathrm{CP}\right.$, ferro: $\mathrm{O}_{2}$-oxidoreductase) is a glycosylated multi-copper ferroxidase that is synthesized primarily in the liver and is abundant in the plasma and interstitial fluid. It has been estimated to bind to $40-70 \%$ of total plasma copper in normal adults, and is the principle mode of copper storage in the body [1,2]. Additionally, the copper harbored by ceruloplasmin is available for uptake by tissues throughout the organism and, thus, one basic function of this "moonlighting protein" is $\mathrm{Cu}$ transport and delivery to tissues [3]. Copper ions are important for a large variety of the enzymatic activities of CP. Possessing ferroxidase activity, this enzyme plays an incontrovertible role in controlling iron turnover and homeostasis. Indeed, the oxidation of ferrous iron to its ferric state by $\mathrm{CP}$ is essential for the mobilization and release of iron from cellular stores, and for uptake 
by the circulating iron transport protein transferrin [4]. According to available data, $\mathrm{CP}$ prevents the participation of $\mathrm{Fe}^{2+}$ in reactions involving $\mathrm{O}_{2}$ and its reduction products, most importantly, $\mathrm{H}_{2} \mathrm{O}_{2}$, resulting in superoxide and hydroxyl radical formation, respectively [5].

Further to this direct antioxidant action, $\mathrm{CP}$ can affect protective enzymatic mechanisms, thus moderating immune responses [6]. Indeed, as the plasma concentration of this copper-containing protein increases from approximately $200-900 \mu \mathrm{g} / \mathrm{mL}$ in response to inflammation, $\mathrm{CP}$ refers to the positive acute-phase proteins. Its synthesis and secretion are also elevated in diabetes mellitus, cancer, cardiovascular and Alzheimer's disease, rheumatoid arthritis, and during pregnancy [6].

$\mathrm{CP}$ has a direct effect on the function of human neutrophils. Particularly, it was reported that $\mathrm{CP}$ inhibits 5-lipoxygenase [7] and a number of serine proteases of leukocyte origin related to inflammatory and septic processes [8]. Anionic CP (pI 4.7) interacts with high affinity with cationic proteins of neutrophils, such as lactoferrin (LF) (pI 8-9) and myeloperoxidase (MPO) (pI 9-10) [9,10]. MPO is an enzyme found predominantly in neutrophils [11]. When it is secreted from activated neutrophils, the likelihood of its interaction with $\mathrm{CP}$ is high due to the increased concentration of the latter in inflammation loci [12]. During inflammation, $\mathrm{CP}$ is protective against oxidant production by MPO. The formation of a specific complex between $\mathrm{CP}$ and $\mathrm{MPO}$ has been described [13]. The entrance of the heme pocket (active center) of MPO interacts with the protease-sensitive loop between the 5th and 6th domains of CP (883-892) in the conventional 3D-model of the 2CP-MPO complex. The copper-free peptide RPYLKVFNPR, corresponding to sequence $883-892$ of CP, exhibits potent inhibition of MPO; in contrast, CP subjected to limited proteolysis loses its efficiency as an inhibitor of MPO [13].

Despite a large amount of accumulating information, many gaps remain in the understanding of the nature of the effect of $\mathrm{CP}$ on neutrophil function. Research in this area is complicated by the fact that in inflammation loci, particularly in the synovial fluid of rheumatoid arthritis patients, a mixture of intact proteins and a greater or lesser degree of proteolyzed molecules must be considered [14].

Shifts in polymorphonuclear leukocyte (PMNL) redox status, as well as deviations in apoptosis propensity, have been considered to underlie several chronic inflammatory diseases. This indicates that studies on all possible elements involved in these regulatory mechanisms are important. This work is a comparative study of the in vitro effects of ceruloplasmin and its derivatives on neutrophil oxidative status and lifespan. The authors hypothesized that the fine-tuning of neutrophil activity by CP and its derivatives would in turn be adjusted under priming conditions similar to those seen during acute or chronic inflammatory events. The authors selected the cytokine TNF- $\alpha$ to model this in vitro.

\section{Materials and Methods}

\subsection{Enzyme Isolation}

CP was isolated from heparin-stabilized plasma of healthy donors and purified using ion-exchange chromatography with UNO-Sphere $\mathrm{Q}$ and affinity chromatography with neomycin-agarose [15]. Proteolyzed CP (CPprot) was obtained after limited proteolysis for $2 \mathrm{~h}$ at $37^{\circ} \mathrm{C}$ with human thrombin $(100: 1, w / w)$. Thrombin was removed immediately after incubation using benzamidine-agarose chromatography. Molecular masses of $\mathrm{CP}$ and $\mathrm{CP}$ prot fragments were evaluated with the help of SDS-electrophoresis in high-molarity Tris-buffer system polyacrylamide gel [16]. SDS-PAGE of CPprot resulted in only fragments of 116, 72, 67, 52, and $19 \mathrm{kDa}$ [14] (Table 1). Apo-CP was obtained by adding ascorbic acid $(0.1 \mathrm{M})$, sodium azide $(0.1 \mathrm{M})$, and EDTA $(0.5 \mathrm{M})$ to $20 \mu \mathrm{M}$ CP. Colorless protein was dialyzed against $0.1 \mathrm{M}$ EDTA ( $\mathrm{pH}$ 8.0) for $24 \mathrm{~h}$, and then three 12-h periods against PBS (at $4{ }^{\circ} \mathrm{C}$ ). Based on atomic absorption results, apo-CP in this preparation contained less than 0.05 copper atoms per molecule. The absence of trace amounts of chelating agents was proven by special control experiments [7]. The percent of CP fragments was calculated by a densitometric analysis performed using ImageJ software (Table 1). Purity of $\mathrm{CP}$ and composition of CPprot fragments is presented on Figure S1 in Supplementary file. 
Table 1. Quantitative evaluation of protein preparations.

\begin{tabular}{ccc}
\hline Compound & $\mathbf{A}_{\mathbf{6 1 0}} / \mathbf{A}_{\mathbf{2 8 0}}$ & $\mathbf{M}$ (Percentage), kDa \\
\hline Intact CP & $>0.050$ & $132(94 \%), 116(2 \%), 19(2 \%)$ \\
CPprot & $>0.049$ & $116(18 \%), 72(16 \%), 67(16 \%)$, \\
Apo-CP & $<0.0001$ & $52(16 \%), 19(34 \%)$ \\
\end{tabular}

During this study, the authors used synthetic amino acid sequences purified by high-performance liquid chromatography (NPF Verta, Saint-Petersburg, Russia). The amino acid sequences of the peptides used in this study are presented in Table 2.

Table 2. Amino acid sequences of the peptides used in this study.

\begin{tabular}{ccc}
\hline Abbreviation & Amino Acid Sequence & Molecular Mass (Da) \\
\hline P1 & RPYLKVFNPR (883-892) & 1290 \\
P2 & RRPYLKVFNPRR & 1600 \\
& $(882-893)$ & \\
\hline
\end{tabular}

Lactoferrin (LF) was isolated from the breast milk of healthy volunteers using ion-exchange chromatography with CM-Sepharose, and by gel-filtration with Sephadex G-100 Superfine [10]. Recombinant human tumor necrosis factor- $\alpha$ (TNF- $\alpha$ ) was from PeproTech (Rocky Hill, NJ, USA).

\subsection{Ethics Statement}

The authors prepared neutrophils from the blood of healthy volunteers. Blood was collected via venous puncture, as approved by the Ministry of Public Health Service of the Russian Federation. Experimental and subject consent procedures were approved by the Institutional Ethics Committee of the A. N. Belozersky Institute of Physico-Chemical Biology, Moscow State University.

\subsection{Human Neutrophil Isolation}

Regarding neutrophil preparations, PMNLs were isolated from freshly drawn citrate-anti-coagulated donor blood by standard techniques, as previously described [17]. The authors prepared leukocyte-rich plasma through the sedimentation of red blood cells (RBCs) using 3\% dextran T-500 at room temperature. Granulocytes were then purified by centrifugation of leukocyte-rich plasma using Ficoll-Paque (density $1.077 \mathrm{~g} / \mathrm{mL}$ ), followed by hypotonic lysis of the remaining RBCs. PMNLs were washed twice with phosphate buffered saline (PBS), resuspended at $10^{7} / \mathrm{mL}$ (purity 96-97\%, viability 98-99\%) in Dulbecco's PBS containing $1 \mathrm{mg} / \mathrm{mL}$ glucose (without $\mathrm{CaCl}_{2}$ ), and stored at room temperature.

\subsection{Reactive Oxygen Species (ROS) Analysis}

\subsubsection{Assessment of Extracellular Superoxide Radicals by Cytochrome C Reduction}

Extracellular production of superoxide anion $\left(\cdot \mathrm{O}_{2}{ }^{-}\right.$was measured by the SOD-inhibitable reduction of ferricytochrome c (Cyto C) $[18,19]$. Briefly, human neutrophils $\left(10^{6} / \mathrm{mL}\right)$ were cultured in HBSS/HEPES containing $25 \mu \mathrm{M}$ Cyto $\mathrm{C}$ and test substances in fibrinogen-coated 24-well plates for $30 \mathrm{~min}$ at $37{ }^{\circ} \mathrm{C}$ in $5 \% \mathrm{CO}_{2}$. To create positive controls, oxidative activity was stimulated with phorbol 12-myristate 13-acetate (PMA) at a concentration of $1 \mathrm{nM}$. The assay was performed in the presence and absence of $\mathrm{Cu} / \mathrm{Zn}-\mathrm{SOD}(30 \mathrm{U} / \mathrm{mL})$. The rate of Cyto $\mathrm{C}$ reduction was measured by recording the differences between absorption values at 550 and $531 \mathrm{~nm}$. To control cell-free experiments, the test compounds were incubated with $25 \mu \mathrm{M}$ Cyto $\mathrm{C}$ under the same conditions. 
The hypoxanthine $(\mathrm{HX}, 100 \mu \mathrm{M})$-xanthine oxidase $(\mathrm{XO}, 0.005 \mathrm{U} / \mathrm{mL})$ system was used to generate superoxide anions [20,21]. The rate of $C y$ to $C$ reduction was measured as indicated previously herein.

\subsubsection{Assessment of Intracellular $\cdot \mathrm{O}_{2}{ }^{-}$Formation Using Dihydroethidium}

Intracellular $\cdot \mathrm{O}_{2}{ }^{-}$production was monitored by red fluorescence measurements on products of the reaction between superoxide and dihydroethidium (DHE). The cells $\left(10^{6} / \mathrm{mL}\right)$ were incubated in HBSS/HEPES supplemented with $10 \mu \mathrm{g} / \mathrm{mL}$ DHE and test substances. To create positive controls, oxidative activity was stimulated using phorbol 12-myristate 13-acetate (PMA) at a concentration of $1 \mathrm{nM}$. PMNLs were cultured for $60 \mathrm{~min}$ at $37^{\circ} \mathrm{C}$ in $5 \% \mathrm{CO}_{2}$. Then, samples were analyzed using a Cytomics FC 500 Flow Cytometry System. Fluorescence was collected by photomultipliers at $590 \mathrm{~nm}$ and $620 \mathrm{~nm}$ [6]. Representing each acquisition, at least 10,000 events were collected within $90 \mathrm{~s}$ of measurement.

\subsubsection{Assessment of Intracellular ROS Formation Using $2^{\prime}, 7^{\prime}$-Dichlorofluorescein-Diacetate (DCFH-DA)}

Intracellular ROS formation was monitored by fluorometric measurements of green fluorescence (excitation: $485 \mathrm{~nm}$, emission: $535 \mathrm{~nm}$ ) after incorporation of carboxy- $\mathrm{H}_{2}$ DCF-DA ( $5 \mu \mathrm{M}$; ThermoFisher Scientific, Waltham, MA, USA), in accordance with the manufacturer's protocol. Briefly, human neutrophils were incubated with $5 \mu \mathrm{M}$ carboxy- $\mathrm{H}_{2} \mathrm{DCF}-\mathrm{DA}$ for $60 \mathrm{~min}$ at room temperature which was followed by washing with PBS. Cells were seeded in fibrinogen-coated 24-well plates $\left(10^{6} / \mathrm{mL}\right.$, in HBSS/HEPES) and treated with the investigated compounds for $60 \mathrm{~min}$ at $37^{\circ} \mathrm{C}$ in $5 \% \mathrm{CO}_{2}$. To control cell-free assays, $10 \mu \mathrm{M}$ carboxy- $\mathrm{H}_{2}$ DCF-DA was incubated with intact $\mathrm{CP}, \mathrm{CPprot}$, and apo-CP $(0.05-2 \mu \mathrm{M})$ in PBS for $30 \mathrm{~min}$ at $37^{\circ} \mathrm{C}$. The increase in fluorescence was then monitored with a fluorometric plate reader CLARIOstar (BMG Labtech, Ortenberg, Germany), exciting the sample at $480 \mathrm{~nm}$ and reading at $530 \mathrm{~nm}$.

\subsection{Apoptosis Detection by Flow Cytometry}

\subsubsection{Double Alexa Fluor-Conjugated Annexin-V and Propidium Iodide Labeling}

To detect phosphatidylserine externalization as one of the earliest indicators of apoptosis, and to ensure that the mechanism of observed cell death was through apoptosis and not necrosis, neutrophils were double-stained with Alexa Fluor-conjugated Annexin V and propidium iodide (PI). PMNLs were suspended at a density of $1 \times 10^{6}$ cells $/ \mathrm{mL}$ in RPMI-1640 medium supplemented with sodium bicarbonate, $2 \mathrm{mM}$ L-glutamine, and $20 \mathrm{mM}$ HEPES, with or without the tested compounds. Cells were cultured in 24-well plates for 5 and $16-20 \mathrm{~h}$ at $37^{\circ} \mathrm{C}$ in a $5 \% \mathrm{CO}_{2}$ incubator. Following incubation, cells were collected by centrifugation at $270 \times g$ and washed once with cold PBS. Cell pellets were resuspended in $100 \mu \mathrm{L}$ HBSS/HEPES containing $2.5 \mu \mathrm{L}$ Annexin V-Alexa Fluor ${ }^{\circledR} 488$ commercial $^{2}$ solution as specified in the manufacturer's instructions. Following $10 \mathrm{~min}$ on ice, $300 \mu \mathrm{L}$ PI solution $(10 \mu \mathrm{g} / \mathrm{mL}$ HBSS/HEPES) was added for $5 \mathrm{~min}$. The samples were analyzed using a Cytomics FC 500 Flow Cytometry System (Beckman Coulter, Krefeld, Germany) with CXP software. Fluorescence was collected by photomultipliers at $525 \mathrm{~nm}$ (Annexin V-Alexa Fluor ${ }^{\circledR} 488$ ) and $620 \mathrm{~nm}$ (PI). Representing each acquisition, at least 10,000 events were collected within $90 \mathrm{~s}$ of measurement.

\subsubsection{Assessment of DNA Fragmentation by PI Staining of Hypo-Diploid Nuclei}

PMNL apoptosis was assessed according to the percent of cells with hypo-diploid DNA content (SubG1 subpopulation), using the technique described by Nicoletti et al. [22]. Briefly, PMNLs were incubated as described previously herein. Upon reaching the end of the desired period, cells were harvested, supplemented with ice-cold $0.05 \%$ BSA in PBS and collected by centrifugation at $270 \times g$, which was followed by permeabilization in cold hypotonic PI solution $(20 \mu \mathrm{g} / \mathrm{mL}$ PI and $0.2 \mathrm{mg} / \mathrm{mL}$ RNase in $0.1 \%$ triton $\mathrm{X}-100$ in $0.1 \%$ sodium citrate). The tubes were placed at $4{ }^{\circ} \mathrm{C}$ in the 
dark for 10-15 min before flow-cytometric analysis using a Cytomics FC 500 System and a 620-nm long-pass filter.

\subsubsection{Terminal Deoxynucleotidyl Transferase dUTP Nick End Labeling (TUNEL)}

Neutrophils apoptosis was detected and quantified by measuring fragmented DNA by catalytically incorporating fluorescein-12-dUTP at $3^{\prime}-\mathrm{OH}$ DNA ends using the recombinant terminal deoxynucleotidyl transferase (rTdT), according to the manufacturer's instructions (DeadEnd ${ }^{\mathrm{TM}}$ Fluorometric TUNEL System, Promega, Madison, WI, USA). PMNLs were incubated as described. Following incubation, cells were collected by centrifugation at $270 \times g$, washed once in cold PBS, resuspended in PBS and fixed with methanol-free paraformaldehyde (final concentration 1\%) for $10 \mathrm{~min}$ at $37^{\circ} \mathrm{C}$. Next, PMNLs were centrifuged at $270 \times g$, washed once in PBS, and permeabilized with $70 \%$ ice-cold ethanol for $30 \mathrm{~min}$ on ice. Fixed and permeabilized PMNLs were collected, washed once in PBS and resuspended in Equilibration buffer for $5 \mathrm{~min}$. Probes were then centrifugated and pellets were resuspended in rTdT Incubation buffer comprising both nucleotide mix and rTdT enzyme. Probes were incubated for $60 \mathrm{~min}$ at $37^{\circ} \mathrm{C}$ in the dark. The reaction was terminated by adding SSC buffer followed by washing with PBS. Representing negative controls, fixed and permeabilized cells were treated with Incubation buffer including only the nucleotide mix and not containing rTdT. Labeled PMNLs were analyzed using CytoFLEX Flow Cytometer system (Beckman Coulter, Krefeld, Germany) measuring green fluorescence of fluorescein-12-dUTP at $525 \mathrm{~nm}$.

\subsection{Statistics}

Results are reported as mean \pm SEM. Analysis of the statistical significance was evaluated using a one-way ANOVA with an appropriate post-test, using GraphPadPrism6 software. $p$ values of less than 0.05 were considered significant. Data were compared against the unstimulated control and the TNF- $\alpha$-stimulated samples.

\section{Results}

3.1. Intact and Partially-Proteolyzed Ceruloplasmin Have a Dual Effect on the Oxidant Status of Resting and TNF- $\alpha$-Stimulated Neutrophils

To identify the test compounds that affect PMNL redox status, the authors employed several approaches, considering the specificity and limitations of each probe used to analyze oxidative burst in neutrophils [23-25]. When measured by SOD-dependent cytochrome $c$ reduction, unlike apo-CP or synthetic peptides, $\mathrm{CP}$ and especially CPprot reduced spontaneous, and completely extinguished TNF- $\alpha$-induced extracellular $\cdot \mathrm{O}_{2}{ }^{-}$generation (Figure 1A,B). Featured in control cell-free experiments tested compounds did not affect reduced Cyto $\mathrm{C}$ accumulation (Figure 1C).

$\mathrm{CP}$ or CPprot were found to reduce intracellular $\cdot \mathrm{O}_{2}{ }^{-}$levels, similar to that observed in unstimulated cells, with the addition of TNF- $\alpha$, whereas the other enzyme derivatives did not exhibit any reliable effect (Figure 2). This was shown by the measurement of DHE oxidation since this probe is known to be sensitive and responsive to $\cdot \mathrm{O}_{2}{ }^{-}$[26]. These facts confirm and supplement previous data [7].

Examining the oxidative status of neutrophils with cell-permeable $\mathrm{H}_{2}$ DCF-DA showed a significant increase in the fluorescence emission of the DCF oxidation product when CP or CPprot were added to PMNLs. Concurrently, the synthetic peptides P1 and P2 weakly inhibited the generation of intracellular oxidants (Figure 3A). The addition of TNF- $\alpha$ by itself had a negligible effect on neutrophil redox status. However, it contributed to a decrease in the influence of CP and CPprot on oxidant formation to some degree (Figure 3A).

Regarding control cell-free experiments, $\mathrm{H}_{2}$ DCF-DA-oxidase activity of $\mathrm{CP}$ was confirmed. Intact CP and CPprot oxidized $2^{\prime}, 7^{\prime}$-dichlorofluorescin diacetate in a dose-dependent manner; however, apo-CP did not demonstrate such activity (Figure 3B). Considering this fact, additional experiments 
were carried out in which PMNLs were treated with copper sulfate $\left(\mathrm{CuSO}_{4}\right)$ at concentrations of $1-3 \mu \mathrm{M}$. The addition of inorganic copper did not lead to the accumulation of intracellular $\mathrm{H}_{2} \mathrm{DCF}$ oxidants (data not shown). This led the authors to consider the revealed action as a biological effect of intact and proteolyzed ceruloplasmin, rather than just a product of free copper ions released from these compounds.

A
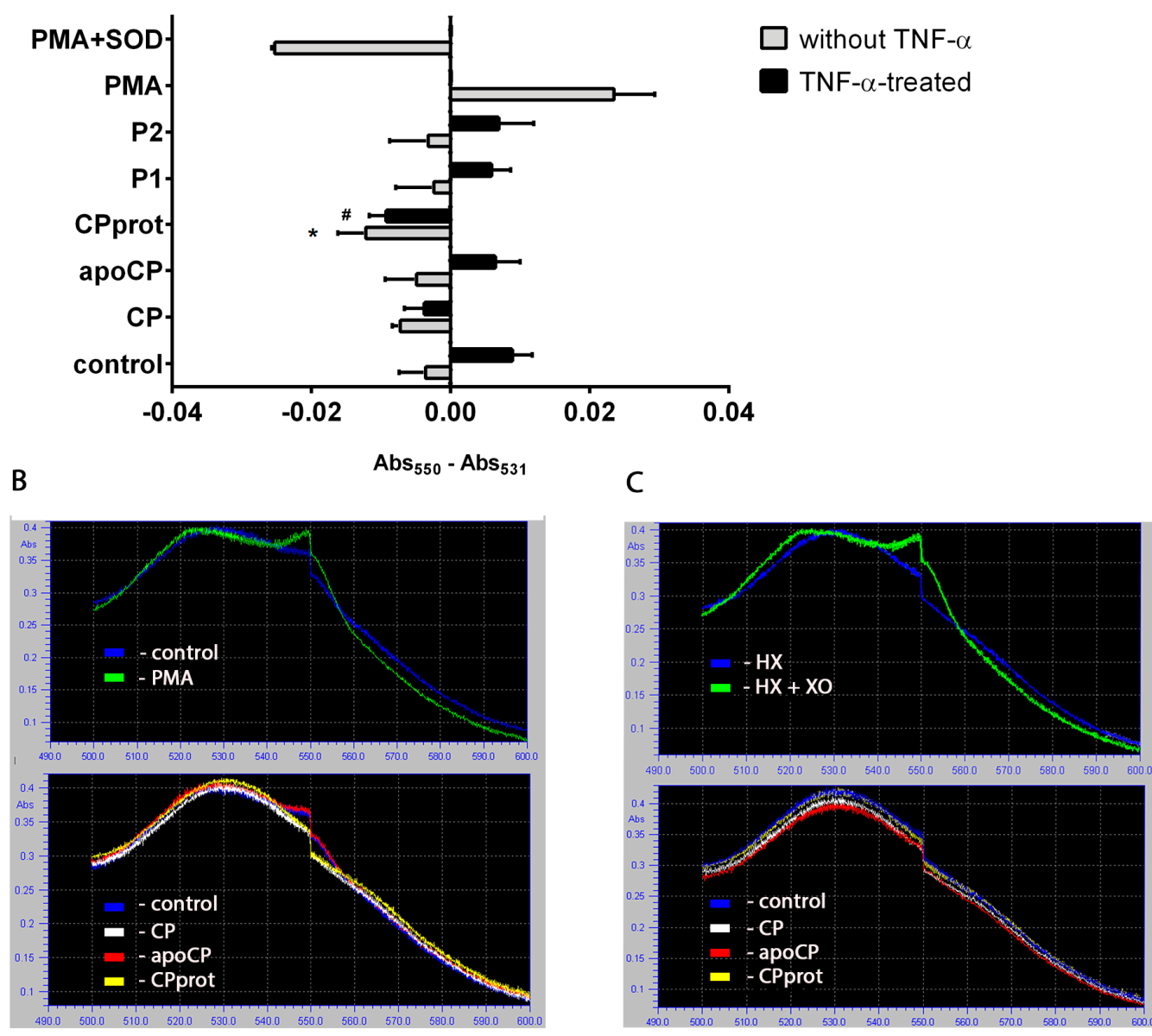

Figure 1. Effects of ceruloplasmin $(\mathrm{CP})$ and its derivatives on superoxide generation by neutrophils and cell-free cytochrome c (Cyto C) reduction. (A) Polymorphonuclear leukocytes (PMNLs; $10^{6} / \mathrm{mL}$ ) were supplemented with Cyto $\mathrm{C}$ and cultured with $0.5 \mu \mathrm{M} \mathrm{CP}, 0.5 \mu \mathrm{M}$ apo-CP, $0.5 \mu \mathrm{M}$ CPprot (proteolyzed ceruloplasmin), or $20 \mu \mathrm{M}$ peptides (P1 or P2), with or without $25 \mathrm{ng} / \mathrm{mL}$ TNF- $\alpha$. Phorbol 12-myristate 13-acetate (PMA; $1 \mathrm{nM}$ ) and $30 \mathrm{U} / \mathrm{mL}$ superoxide dismutase (SOD) were used as positive and negative controls, respectively. Cells were incubated in 24-well plates for $30 \mathrm{~min}$ at $37^{\circ} \mathrm{C}$. The rate of Cyto $\mathrm{C}$ reduction was measured by the change in differences between absorptions at 550 and $531 \mathrm{~nm}$. Values represent the means \pm SEM of $\Delta(550 / 531)$ of duplicate cultures from six independent experiments; ${ }^{*}, \# p<0.05$ compared to control (medium) and TNF- $\alpha$-treated PMNLs, respectively (one-way ANOVA followed by Holm-Šídák multiple comparison tests). (B) Representative spectra recorded at 600-500 $\mathrm{nm}$ of Cyto $\mathrm{C}$ reduction in PMNL incubations with apo-CP, CP, CPprot, and PMA. C. Cyto $C$ was incubated with $0.5 \mu \mathrm{M} \mathrm{CP}, 0.5 \mu \mathrm{M}$ apo-CP, $0.5 \mu \mathrm{M}$ CPprot or with $100 \mu \mathrm{M}$ HX $+0.005 \mathrm{U} / \mathrm{mL}$ XO following spectra recording as above. 
A

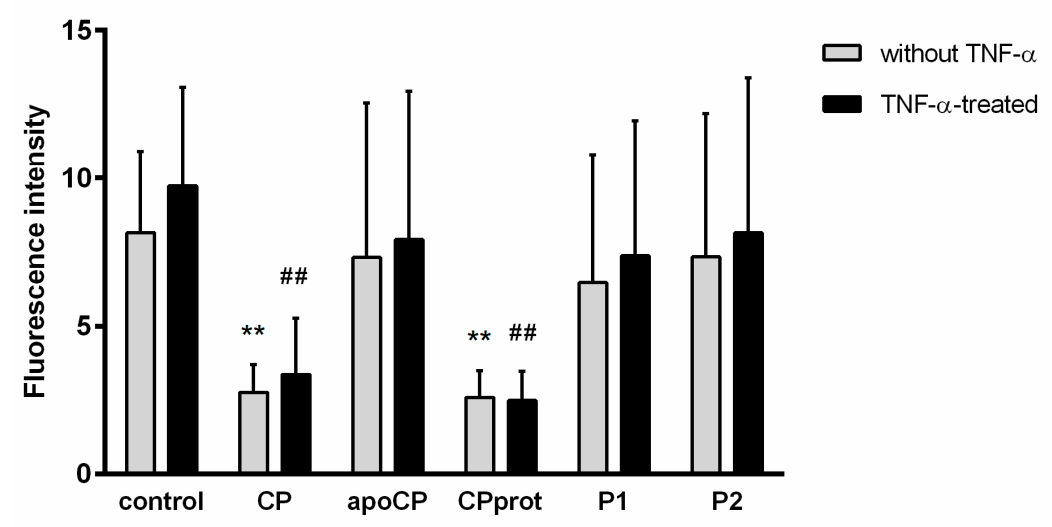

B

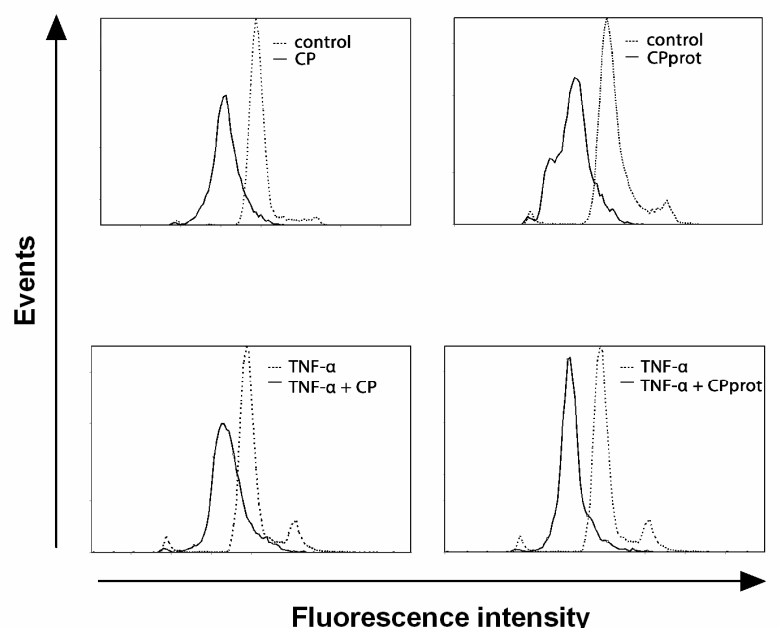

Figure 2. Effects of ceruloplasmin (CP) and its derivatives on intracellular superoxide generation by neutrophils. Dihydroethidium (DHE)-stained polymorphonuclear leukocytes (PMNLs) were cultured with $0.5 \mu \mathrm{M} \mathrm{CP}, 0.5 \mu \mathrm{M}$ apo-CP, $0.5 \mu \mathrm{M}$ proteolyzed CP (CPprot), or $20 \mu \mathrm{M}$ peptides (P1 or P2), with or without $25 \mathrm{ng} / \mathrm{mL}$ TNF- $\alpha$ for $60 \mathrm{~min}$ at $37^{\circ} \mathrm{C}$, which was followed by flow cytometric measurements of red fluorescence. (A) Values represent the means \pm SEM of fluorescence intensities, arbitrary units of duplicate cultures from four independent experiments; ${ }^{* *}, \#$ \# $p<0.01$, compared to the control (medium) and TNF- $\alpha$-treated PMNLs, respectively (one-way ANOVA followed by Holm-Šídák multiple comparison tests). (B) Representative histograms of PMNL distribution according to accumulation of DHE oxidation products.

Since reactive nitrogen species are known to be possible $\mathrm{H}_{2} \mathrm{DCF}$ oxidants [27], additional experiments using DAF-2 DA, a cell permeable probe for the measurement nitric oxide synthase activity, were performed. These assays did not reveal any effect of the investigated compounds on nitric oxide levels.

When TNF- $\alpha$ is added, endogenous LF release occurs [28], which helps to stabilize the enzyme, and thereafter retain copper. Indeed, the addition of exogenous LF inhibited oxidant formation induced by $\mathrm{CP}$ and $\mathrm{CPprot}$ (Figure 3C).

Considering the data indicating that neutrophil life span is dictated by the redox status of the cell [29], we performed experiments to explore whether CP derivatives themselves or in conjunction with TNF- $\alpha$ affect PMNL apoptosis. 


\section{A}

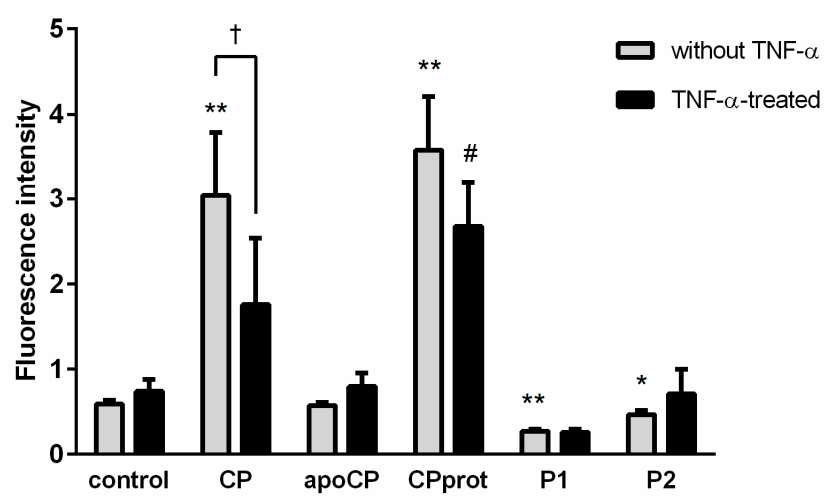

B

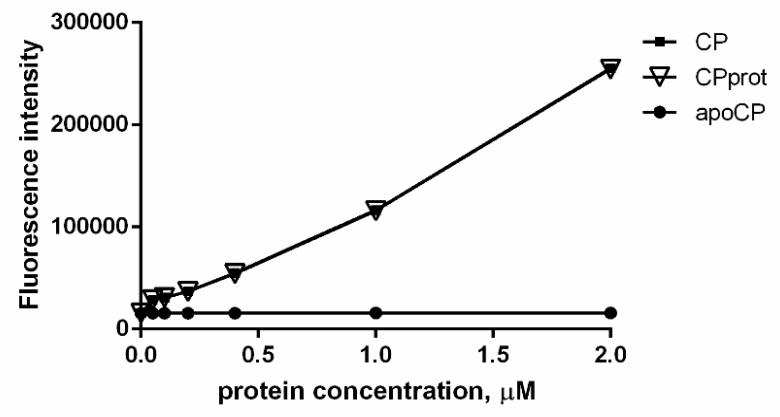

C

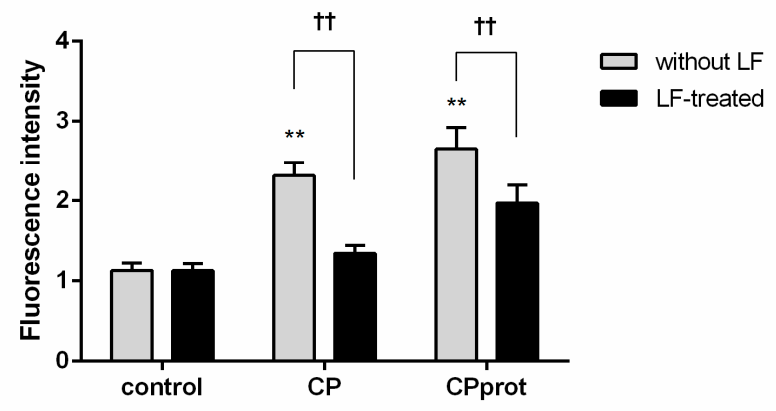

Figure 3. Effects of ceruloplasmin (CP) and its derivatives on intracellular reactive oxygen species (ROS) generation by neutrophils. $\mathrm{H}_{2}$ DCF-DA stained polymorphonuclear leukocytes (PMNLs) were cultured with $0.5 \mu \mathrm{M} \mathrm{CP}, 0.5 \mu \mathrm{M}$ apo-CP, $0.5 \mu \mathrm{M}$ CPprot (proteolyzed $\mathrm{CP}$ ), or $20 \mu \mathrm{M}$ peptides (P1 or P2), with or without $25 \mathrm{ng} / \mathrm{mL}$ TNF- $\alpha$ (A) or $1 \mu \mathrm{M}$ lactoferrin (LF) (C) for $60 \mathrm{~min}$ at $37^{\circ} \mathrm{C}$ followed by fluorometric measurements of green fluorescence. (B) $\mathrm{H}_{2}$ DCF-DA-oxidase activity of intact CP, CPprot $(0.05-2 \mu \mathrm{M})$ in cell-free assay. Apo-CP was used as a control. Values represent the means \pm SEM of fluorescence intensities, arbitrary units of duplicate cultures from six independent experiments; ${ }^{*} p<0.05,{ }^{* *} p<0.01$, compared to the control (medium); ${ }^{*} p<0.05$, compared to TNF- $\alpha$-treated PMNLs; ${ }^{+} p<0.05,{ }^{+\dagger} p<0.01$ for pairs of data compared (one-way ANOVA followed by Holm-Šídák multiple comparison tests). 


\subsection{CP and Its Derivatives Inhibit Spontaneous PMNL Apoptosis}

PMNLs were incubated with no additives or in the presence of intact $\mathrm{CP}$, apo- $\mathrm{CP}, \mathrm{CPprot}$, or peptide $\mathrm{P} 1$ and $\mathrm{P} 2$, corresponding to fragments of $\mathrm{CP}$. Subsequently phosphatidylserine exposure and plasma membrane integrity loss were analyzed by double Alexa Fluor-conjugated Annexin- $V$ and PI labeling. Regarding control and test samples, a negligible number of necrotic PMNLs was detected, even after prolonged $(20 \mathrm{~h})$ culturing (Figure $4 \mathrm{~A})$.

A
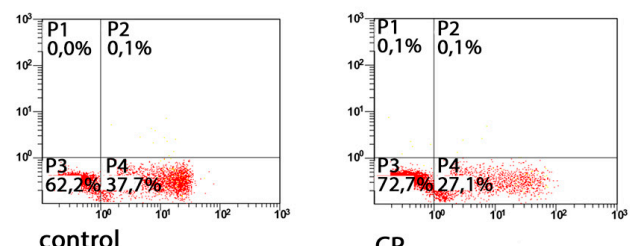

$\mathrm{CP}$
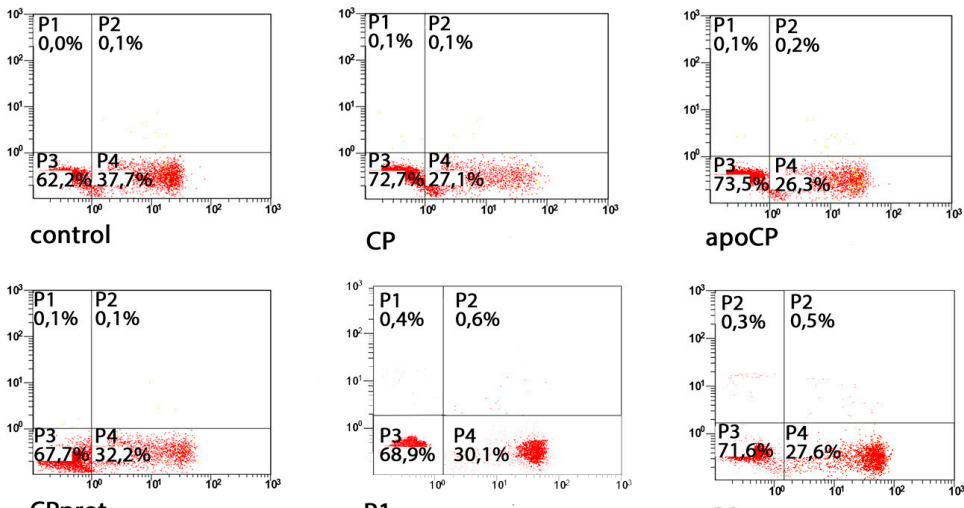

P1

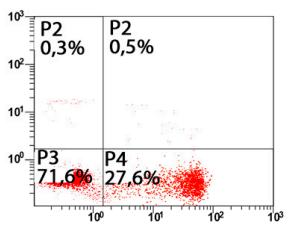

P2

B

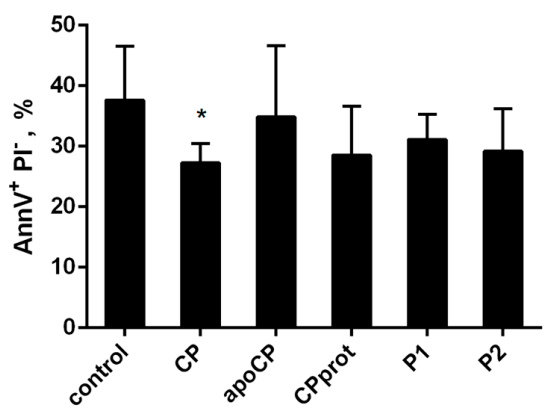

Figure 4. Spontaneous apoptosis of human neutrophils after exposure to ceruloplasmin (CP) or its derivatives. Polymorphonuclear leukocytes (PMNLs; $10^{6} / \mathrm{mL}$ ) were cultured for $20 \mathrm{~h}$ at $37^{\circ} \mathrm{C}$ without additives or with $0.5 \mu \mathrm{M}$ intact $\mathrm{CP}, 0.5 \mu \mathrm{M}$ apo-CP, $0.5 \mu \mathrm{M}$ CPprot (proteolyzed $\mathrm{CP}$ ), or $20 \mu \mathrm{M}$ peptides (P1 or P2). The percentage of Annexin V- or propidium iodide (PI)-positive cells was determined by flow cytometry. (A) Representative dot plots for phosphatidylserine externalization by apoptotic cells, as well as the proportions of viable (region P3), early apoptotic (region P4), and late apoptotic and necrotic cells (regions P2 and P1) are indicated. (B) Presented are pooled data with the percentage of apoptotic cells. Values indicate the mean \pm SEM of duplicate cultures from three independent experiments; ${ }^{*} p<0.05$, compared to control (one-way ANOVA followed by Holm-Š́iák multiple comparison tests).

The authors found no statistically significant modulatory effects on PMNL apoptosis for $\mathrm{CP}$ and its derivatives with short-term incubation $(5 \mathrm{~h})$. However, prolonged exposure to the proteins and peptides slightly but stably suppressed spontaneous apoptosis, as revealed using both phosphatidylserine externalization detection (Figure 4) and assessment of nuclear DNA fragmentation by SubG1 PMNLs estimation (Figure 5) or TUNEL assay (Figure 6C) followed by flow cytometric analysis. When compared to that in control samples, the growth of living cells number was more pronounced for intact $\mathrm{CP}$ (Figures $4 \mathrm{~B}$ and $5 \mathrm{~A}$ ). 
A

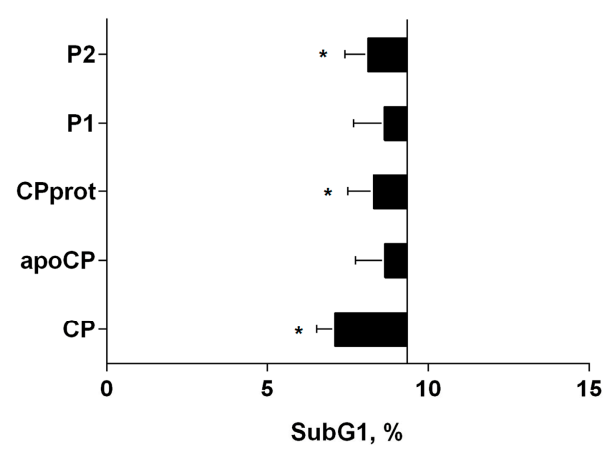

B

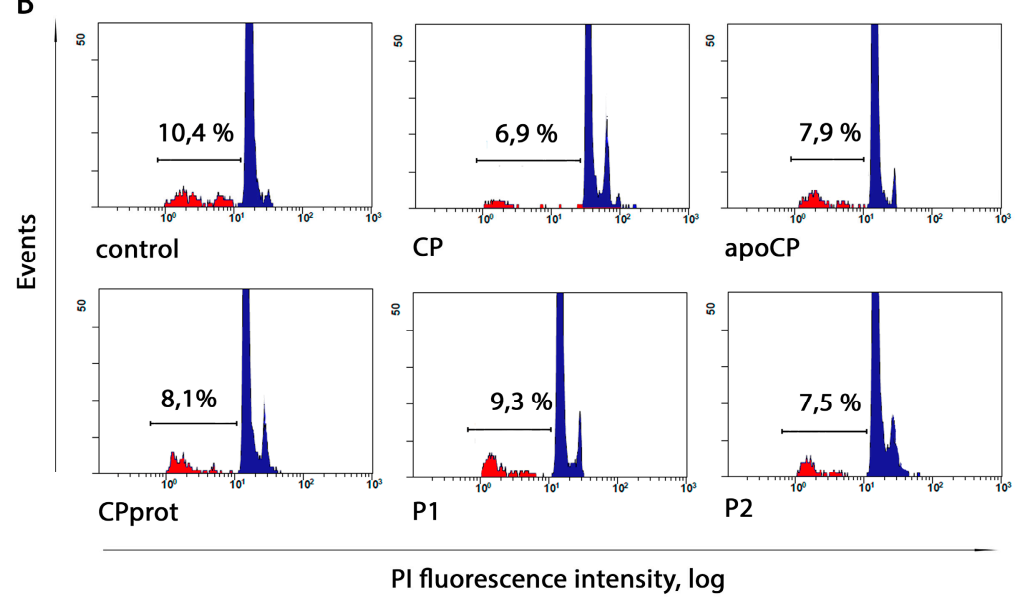

Figure 5. Effect of ceruloplasmin (CP) and its derivatives on spontaneous neutrophil apoptosis. Polymorphonuclear leukocytes (PMNLs; $10^{6} / \mathrm{mL}$ ) were cultured at $37^{\circ} \mathrm{C}$ with $0.5 \mu \mathrm{M}$ intact $\mathrm{CP}, 0.5 \mu \mathrm{M}$ apo-CP, $0.5 \mu \mathrm{M}$ CPprot (proteolyzed CP), or $20 \mu \mathrm{M}$ peptides (P1 or P2) for $20 \mathrm{~h}$ and assayed for the proportion Sub G1 PMNLs by flow cytometry. (A) Apoptosis levels induced by the indicated compounds. Bars begin at the control line (which corresponds to $9.3 \pm 0.77 \%$ ), values indicate the mean \pm SEM of duplicate cultures from six independent experiments; ${ }^{*} p<0.05$, compared to control (one-way ANOVA followed by Holm-Šídák multiple comparison tests). (B) Representative histograms of nuclear DNA fragmentation.

\subsection{Proteolyzed Ceruloplasmin Enhances the Pro-Apoptotic Effect of TNF- $\alpha$, Whereas the Intact Protein Retains Pro-Survival Properties}

It is known that TNF- $\alpha$ is one of the cytokines that are part of the acute phase reaction, and this molecule plays a critical role in the pathogenesis of chronic inflammatory diseases by eliciting a broad spectrum of cellular responses, including proliferation, differentiation, and apoptosis. Considering that, the authors investigated whether $\mathrm{CP}$, or its derivatives, and TNF- $\alpha$, added at a potentially apoptogenic dose $(25 \mathrm{ng} / \mathrm{mL})$ simultaneously with the tested compounds, mutually influence the apoptosis-modifying properties of each other. Notably, in these experiments, TNF- $\alpha$ affected neutrophil viability in an irregular manner. Treatment with this cytokine sharply enhanced PMNL apoptosis at early times of incubation. However, with prolonged incubation, the pro-apoptotic activity of TNF- $\alpha$ was markedly diminished, as determined by measuring Annexin-V-positive neutrophils (data not shown) and Sub G1 fractions (Figure 6). These results are generally consistent with data from other research groups confirming the existence of different pathways in TNF- $\alpha$ signaling [30]. 
A

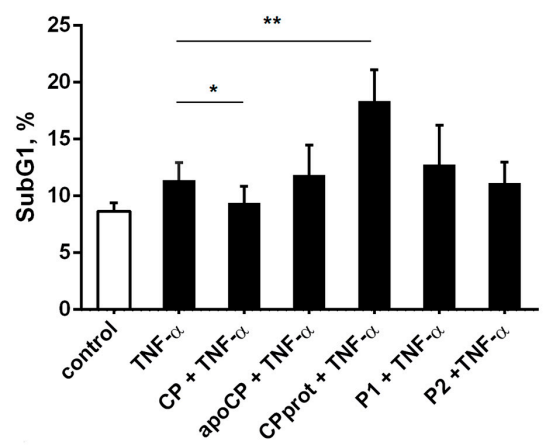

C

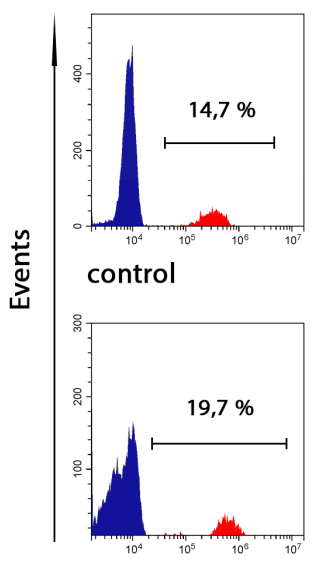

TNF- $a$
B

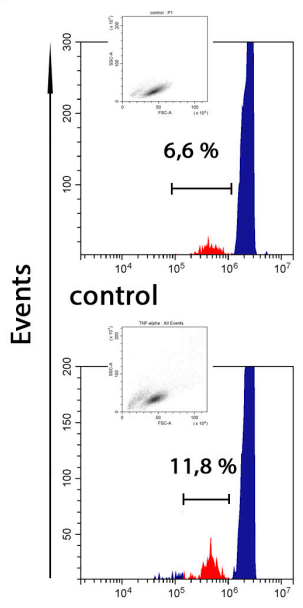

TNF-a
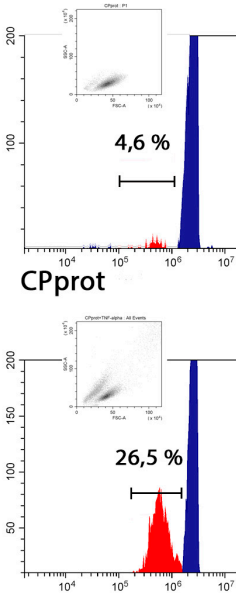

CPprot + TNF-a
PI fluorescence intensity, log

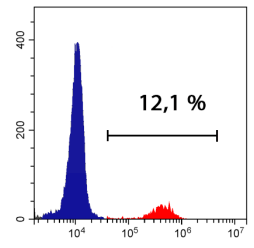

CPprot

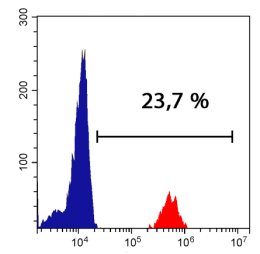

CPprot + TNF-a

FITC fluorescence intensity, log

Figure 6. Neutrophil apoptosis with simultaneous exposure to ceruloplasmin $(\mathrm{CP})$ and its derivatives and TNF- $\alpha$. Polymorphonuclear leukocytes (PMNLs; $10^{6} / \mathrm{mL}$ ) were cultured at $37^{\circ} \mathrm{C}$ with $0.5 \mu \mathrm{M}$ intact $\mathrm{CP}, 0.5 \mu \mathrm{M}$ CPprot (proteolyzed CP), $0.5 \mu \mathrm{M}$ apo-CP, or $20 \mu \mathrm{M}$ peptides (P1 or P2), with or without $25 \mathrm{ng} / \mathrm{mL}$ TNF- $\alpha$ for $20 \mathrm{~h}$; nuclear DNA fragmentation was assayed both by PI staining of hypo-diploid nuclei and by the detection of DNA strand breaks by TUNEL. (A) Presented are pooled data with the percentage of apoptotic cells. Values are the mean \pm SEM of duplicate cultures from six independent experiments; ${ }^{*} p<0.05$ and ${ }^{* *} p<0.01$ (one-way ANOVA followed by Holm-Šídák multiple comparison tests). Representative histograms of apoptotic DNA fragmentation revealed as the SubG1-subpopulation (B) and as labeled with FITC-12-dUTP DNA strand breaks (C).

Upon short-term incubation, simultaneous addition of the tested compounds and TNF- $\alpha$ did not alter the percentage of Annexin-V-positive neutrophils, compared to that in samples treated with TNF- $\alpha$ alone. When neutrophil apoptosis was assessed after prolonged incubation, the authors revealed a significantly augmented TNF- $\alpha$ apoptogenic effect with the simultaneous addition of the cytokine and CPprot, and a slight pro-survival effect with the CP/TNF- $\alpha$ combination (Figure 6). Neither apoCP nor synthetic peptides had any effect on TNF- $\alpha$-induced PMNL apoptosis. 


\section{Discussion}

This study demonstrates that, in contrast to other CP derivatives investigated, the intact enzyme and the product of its partial proteolysis have a pronounced effect on PMNL oxidative status. CP and CPprot reduced extra- and intracellular $\cdot \mathrm{O}_{2}{ }^{-}$levels arising both spontaneously and with TNF- $\alpha$ stimulation. Concurrently, the authors observed a sharp increase in the fluorescence of the oxidation product of $\mathrm{H}_{2} \mathrm{DCF}$, used for nonselective quantitation of intracellular oxidants. Regarding control, cell-free experiments, the authors confirmed the $\mathrm{H}_{2}$ DCF-DA oxidase activity of CP and CPprot (Figure 3B). It was suggested that both effects are associated with the presence of copper in both compounds. Indeed, apo-CP did not prevent the formation of superoxide or the oxidation of DCFH-DA. The mechanisms of superoxide elimination by CP are not completely clear, but the most plausible is the hypothesis that this ability is inextricably linked to the oxidative activity of copper atoms [31,32]. When reduced by superoxide, $\mathrm{Cu}+$ catalyzes hydroxyl radical formation; both oxidized and reduced copper ions catalyze and amplify the formation of ROS, thus affecting intracellular and tissue structures. Estimating the oxidant status using DHE and $2^{\prime}, 7^{\prime}$-dichlorofluorescin diacetate, the authors obtained opposite results: the addition of intact or proteolyzed ceruloplasmin led to a diminution in oxidized DHE fluorescence (Figure 2), but dramatically increased the DCF emission (Figure 3). Such data inconsistency indirectly confirms precisely this mechanism. Moreover, the resulting formation of oxidants leads to structural destabilization of $\mathrm{CP}$, and possibly CPprot, resulting in increased lability of copper associated with both compounds [33,34]. The ability of CP to exhibit both anti-oxidant and pro-oxidant properties persists after its partial proteolysis. Moreover, proteolytic degradation promotes some increase in pro-oxidant activity. Obviously, under conditions of inflammation, when the concentration of CP and, accordingly the products of its hydrolysis, increase, mechanisms regulating pro-oxidant activity must exist. During these experiments, the addition of TNF- $\alpha$ had an inhibitory effect on the formation of intracellular oxidants. This might be due to the stabilization of CP and CPprot by LF, which is released from granules under the control of TNF- $\alpha$.

Intracellular oxidant accumulation often triggers apoptotic pathways; in addition, copper ions which become more accessible due to the oxidative damage of intact and proteolyzed CP might have detrimental intracellular effects. Based on this, and due to similarities between CP and CPprot in terms of their influence on the oxidative status of neutrophils, it was expected that these compounds would identically affect PMNL apoptosis. However, the unidirectional ability to inhibit both spontaneous and TNF- $\alpha$ induced apoptosis was observed only for intact CP, whereas the regulation of apoptosis by derivatives of CP switched from inhibition to activation with the addition of TNF- $\alpha$. The authors emphasize once again that the revealed effects are the bioactivity of $\mathrm{CP}$ and CPprot, since inorganic copper, when added to the cells in relevant concentrations, did not exert the same influence on PMNL oxidative or apoptotic status (data not shown).

Although the molecular mechanisms of these effects are beyond the scope of this study, the authors assume that proteins of neutrophil origin are at the foreground.

MPO is an oxidative enzyme that is capable of inducing oxidative, halogenative, and nitrosative stress in vivo [35]. Hypochlorous acid ( $\mathrm{HOCl})$ is the major oxidant formed by MPO under physiological conditions [36]. Supplemental to its microbicidal action, $\mathrm{HOCl}$ influences the functions of PMNL by modifying proteins, lipids, and DNA, thereby reducing the lifespan of neutrophils themselves [37] as well as neighboring cells [38]. Additionally, MPO was previously shown to be a powerful auto- and paracrine mediator, which can both delay [39] and initiate apoptosis [40,41].

TNF- $\alpha$ plays a critical role in modulating acute and chronic inflammation, largely due to its ability to fine-tune neutrophil functions [28,42,43] and lifespan [44,45]. Specifically, this cytokine markedly stimulates MPO synthesis and secretion. MPO-dependent $\mathrm{HOCl}$ is known to accumulate during long incubations of neutrophils with TNF- $\alpha$ [46] and is facilitated by cytokine-induced cellular adhesion [47]. TNF- $\alpha$ induced degranulation leads to inter alia LF release from secondary granules $[28,48]$.

$\mathrm{CP}$ is known as a physiological inhibitor of MPO pro-oxidative activity [49]. The ability of CP to inhibit the formation of MPO-derived oxidants is obviously another possible contributor to the 
anti-apoptotic activity of intact CP observed in these assays. It should be noted that the processes in question occur during long incubations. The oxidative status of PMNLs was evaluated in short-term experiments. Additionally, it is known that hydrophilic $\mathrm{H}_{2} \mathrm{DCF}$, produced from $\mathrm{H}_{2} \mathrm{DCF}-\mathrm{DA}$ by intracellular cleavage, is unable to penetrate membranes including lysosomal [50]; hence, the method used characterizes the oxidase status of the cytosol, but not the granules. Increased oxidation of $\mathrm{H}_{2} \mathrm{DCF}$ in cell and cell-free assays by $\mathrm{CP}$ indirectly shows the possibility of $\mathrm{CP}$ endocytosis by neutrophils. Therefore, the contradiction regarding the previous assumption and the effect of $\mathrm{CP}$ relating to oxidative status (based on the data) seems to be misleading.

$\mathrm{CP}$ and its derivatives differ in their ability to inhibit MPO peroxidase activity [51]. The limited proteolysis of CP was shown to abrogate its capacity to inhibit the peroxidase activity of MPO [14]. The inability of all compounds except holo-CP to prevent TNF- $\alpha$-induced apoptosis was probably due to decreased affinity of $\mathrm{CP}$ derivatives for the peroxidase enzyme. It also has been established that $\mathrm{CP}$ influences the activities of serprocidins of neutrophil-origin, including proteinase 3 (PR3) [52]. The latter suggests one possible mechanism of the spontaneous death program in aging neutrophils [53]. One can assume that the suppression of spontaneous apoptosis, observed with the compounds studied, occurs through the inhibition of PR3, and that the inhibitory effect would depend on the integrity of the copper protein.

The release of LF from TNF- $\alpha$-treated cells [28] can also contribute to the observed influence of $\mathrm{CP}$ and its derivatives on neutrophil apoptosis. First, LF is the most active protector of CP [54]. Oxidative stress and ROS disrupt copper binding to $\mathrm{CP}$, thereby impairing its normal function [33]. $\mathrm{CP}$ is easily degraded by proteases [55,56]. However, the integrity of the $\mathrm{CP}$ molecule is important for the function of this enzyme. Antioxidant properties such as GSH-dependent peroxidase activity [57] and the inhibition of the chlorinating and peroxidase activity of MPO [14] are lost after proteolytic degradation. Additionally, the enzyme disintegration process itself is accompanied by hydroxyl radical generation [54]. It could be argued that upon TNF- $\alpha$ stimulation, interactions between LF and CP protect the anti-oxidant properties of the latter and prevents excessive $\mathrm{OH} \cdot-$-formation.

Additionally, LF inhibits neutrophil apoptosis such that its pro-survival effect is dependent on its iron saturation status; specifically, iron-saturated LF is incapable of affecting neutrophil life span [58]. CP and LF mutually affect the function of each other. LF promotes the $\mathrm{Fe}^{2+}$ binding and ferroxidase activity of CP [59]. Subsequently, CP stimulates iron incorporation into apo-LF [59]. LF can incorporate ferric ions produced during ferroxidase reactions catalyzed by $\mathrm{CP}$. Therefore, the oxidation of pro-oxidant ferrous ions catalyzed by $\mathrm{CP}$ should increase the iron saturation status of LF and reduce its ability to affect neutrophil apoptosis. This becomes particularly important for proteolyzed CP. Mentioned previously, the latter fails to inhibit the peroxidase activity of MPO [14] but retains its ferroxidase activity, thus, suppressing the anti-apoptotic properties of LF. These results showed that CPprot facilitates a TNF- $\alpha$-induced apoptotic death program in neutrophils, and it is assumed that the aforementioned mechanism is a prerequisite for this event.

It was found that partial proteolysis dramatically reduces the inhibitory function of MPO on $\mathrm{CP}$ without disturbing its ferroxidase activity [14]. CPprot cannot inhibit the peroxidase activity of MPO [14], but retains ferroxidase activity. LF can incorporate ferric ions produced during the ferroxidase reaction catalyzed by $\mathrm{CP}$; for example, LF reduces the oxidation potential of pro-oxidant iron ions [10]. Therefore, oxidation of pro-oxidant ferrous ions catalyzed by CP should increase the iron saturation status of LF and reduce its ability to affect neutrophil apoptosis.

The generation of reactive oxygen, halogen, and nitrogen species by neutrophils has been implicated in the onset and progression of several disorders [35,60]. Although defense against oxidative stress has been demonstrated for $\mathrm{CP}$, many studies have indicated that this protein is able to act as a powerful pro-oxidant factor. Being effective superoxide radical scavengers, these results indicate that, not only intact, but also partially proteolyzed $\mathrm{CP}$, indeed induces an immediate sharp increase in other intracellular oxidants, at least in experimental conditions. Regarding conditions of oxidative stress, $\mathrm{CP}$-derived peptides also possess pro-oxidant activities and potentiate phorbol 
myristate acetate-induced ROS formation [61]. Contrary to the unidirectional effect on PMNL oxidant status, intact and partially proteolyzed CP acted differently on delayed apoptosis. The inhibition of apoptosis observed in the presence of acute phase $\mathrm{CP}$ occurred whether or not PMNLs were exposed to TNF- $\alpha$. The mode of apoptosis regulation by CPprot, as well as other products of enzyme hydrolysis, switches from inhibition to activation in the presence of TNF- $\alpha$. Proteolytic degradation of CP is one characteristic of inflammatory processes. Analysis of the synovial fluid of patients with rheumatoid arthritis revealed that $\mathrm{CP}$ is proteolytically degraded to a variable extent during this inflammatory process [14]. The authors propose that this event represents a potential mechanism associated with the activation of neutrophil apoptosis. The net effect of $\mathrm{CP}$ on neutrophil survival no doubt reflects a balance between the activities of numerous inflammation factors, not only TNF- $\alpha$. The nature and mechanisms of the effects of CP on the non-enzymatic activity of MPO are poorly understood and should be the subject of further research. Nevertheless, it is clear that a holo-CP and the product of its physiological decay are directly involved in the fine regulation of inflammatory processes. To the authors' knowledge, this is the first study demonstrating the regulation of neutrophil apoptosis by $\mathrm{CP}$ and its derivatives.

Supplementary Materials: Supplementary materials are available on line www.mdpi.com/2073-4409/7/1/8/s1.

Acknowledgments: This study was funded by grants, 16-34-00531 and 17-04-01491, from the Russian Foundation for Basic Research. The authors have no conflicting interests to disclose.

Author Contributions: E.A.G., G.M.V., S.I.G., G.F.S. and A.V.S. designed and conducted the experiments. E.A.G., T.V.G., G.F.S. and A.V.S. analyzed the data. E.A.G., G.F.S. and A.V.S. wrote the paper.

Conflicts of Interest: The authors declare no conflict of interest. The founding sponsors had no role in the design of the study, in the collection, analyses, or interpretation of data, in the writing of the manuscript, or in the decision to publish the results.

\section{References}

1. Holmberg, C.G.; Laurell, C.B. Investigations in Serum Copper. II. Isolation of the Copper Containing Protein, and a Description of some of its Properties. Acta Chem. Scand. 1948, 2, 550-556. [CrossRef]

2. Linder, M.C. Ceruloplasmin and other copper binding components of blood plasma and their functions: An update. Metallomics 2016, 8, 887-905. [CrossRef] [PubMed]

3. Tapiero, H.; Townsend, D.M.; Tew, K.D. Trace elements in human physiology and pathology. Copper Biomed. Pharmacother. 2003, 57, 386-398. [CrossRef]

4. Osaki, S.; Johnson, D.A.; Frieden, E. The possible significance of the ferrous oxidase activity of ceruloplasmin in normal human serum. J. Biol. Chem. 1966, 241, 2746-2751. [PubMed]

5. Pierre, J.L.; Fontecave, M. Iron and activated oxygen species in biology: The basic chemistry. Biometals 1999, 12, 195-199. [CrossRef] [PubMed]

6. Varfolomeeva, E.Y.; Semenova, E.V.; Sokolov, A.V.; Aplin, K.D.; Timofeeva, K.E.; Vasilyev, V.B.; Filatov, M.V. Ceruloplasmin decreases respiratory burst reaction during pregnancy. Free Radic Res. 2016, 50, 909-919. [CrossRef] [PubMed]

7. Sokolov, A.V.; Golenkina, E.A.; Kostevich, V.A.; Vasilyev, V.B.; Sud'ina, G.F. Interaction of ceruloplasmin and 5-lipoxygenase. Biochemistry 2010, 75, 1464-1469. [CrossRef] [PubMed]

8. Sokolov, A.V.; Pulina, M.O.; Ageeva, K.V.; Runova, O.L.; Zakharova, E.T.; Vasil'ev, V.B. Identification of leukocyte cationic proteins that interact with ceruloplasmin. Biochemistry 2007, 72, 872-877. [CrossRef] [PubMed]

9. Sokolov, A.V.; Pulina, M.O.; Ageeva, K.V.; Ayrapetov, M.I.; Berlov, M.N.; Volgin, G.N.; Markov, A.G.; Yablonsky, P.K.; Kolodkin, N.I.; Zakharova, E.T.; et al. Interaction of ceruloplasmin, lactoferrin, and myeloperoxidase. Biochemistry 2007, 72, 409-415. [CrossRef] [PubMed]

10. Sokolov, A.V.; Zakharova, E.T.; Kostevich, V.A.; Samygina, V.R.; Vasilyev, V.B. Lactoferrin, myeloperoxidase, and ceruloplasmin: Complementary gearwheels cranking physiological and pathological processes. Biometals 2014, 27, 815-828. [CrossRef] [PubMed]

11. Klebanoff, S.J. Myeloperoxidase: Friend and foe. J. Leukoc. Biol. 2005, 77, 598-625. [CrossRef] [PubMed] 
12. Da Costa, L.A.; García-Bailo, B.; Borchers, C.H.; Badawi, A.; El-Sohemy, A. Association between the plasma proteome and serum ascorbic acid concentrations in humans. J. Nutr. Biochem. 2013, 24, 842-847. [CrossRef] [PubMed]

13. Samygina, V.R.; Sokolov, A.V.; Bourenkov, G.; Petoukhov, M.V.; Pulina, M.O.; Zakharova, E.T.; Vasilyev, V.B.; Bartunik, H.; Svergun, D.I. Ceruloplasmin: Macromolecular assemblies with iron-containing acute phase proteins. PLoS ONE 2013, 8, e67145. [CrossRef] [PubMed]

14. Sokolov, A.V.; Acquasaliente, L.; Kostevich, V.A.; Frasson, R.; Zakharova, E.T.; Pontarollo, G.; Vasilyev, V.B.; De Filippis, V. Thrombin inhibits the anti-myeloperoxidase and ferroxidase functions of ceruloplasmin: Relevance in rheumatoid arthritis. Free Radic. Biol. Med. 2015, 86, 279-294. [CrossRef] [PubMed]

15. Sokolov, A.V.; Kostevich, V.A.; Romanico, D.N.; Zakharova, E.T.; Vasilyev, V.B. Two-stage method for purification of ceruloplasmin based on its interaction with neomycin. Biochemistry 2012, 77, 631-638. [CrossRef] [PubMed]

16. Fling, S.P.; Gregerson, D.S. Peptide and protein molecular weight determination by electrophoresis using a high-molarity tris buffer system without urea. Anal Biochem. 1986, 155, 83-88. [CrossRef]

17. Sud'ina, G.F.; Brock, T.G.; Pushkareva, M.A.; Galkina, S.I.; Turutin, D.V.; Peters-Golden, M.; Ullrich, V. Sulphatides trigger polymorphonuclear granulocyte spreading on collagen-coated surfaces and inhibit subsequent activation of 5-lipoxygenase. Biochem. J. 2001, 359, 621-629. [CrossRef] [PubMed]

18. Hoffstein, S.T.; Gennaro, D.E.; Manzi, R.M. Neutrophils may directly synthesize both $\mathrm{H}_{2} \mathrm{O}_{2}$ and $\mathrm{O}_{2}{ }^{-}$since surface stimuli induce their release in stimulus-specific ratios. Inflammation 1985, 9, 425-437. [CrossRef] [PubMed]

19. Babior, B.M.; Kipnes, R.S.; Curnutte, J.T. Biological defense mechanisms. The production by leukocytes of superoxide, a potential bactericidal agent. J. Clin. Investig. 1973, 52, 741-744. [CrossRef] [PubMed]

20. Hodgson, E.K.; Fridovich, I. The accumulation of superoxide radical during the aerobic action of xanthine oxidase. A requiem for $\mathrm{H}_{2} \mathrm{O}_{4}$. Biochim. Biophys. Acta 1976, 430, 182-188. [CrossRef]

21. Galkina, S.I.; Dormeneva, E.V.; Bachschmid, M.; Pushkareva, M.A.; Sud'ina, G.F.; Ullrich, V. Endothelium-leukocyte interactions under the influence of the superoxide-nitrogen monoxide system. Med. Sci. Monit. 2004, 10, BR307-BR316. [PubMed]

22. Nicoletti, I.; Migliorati, G.; Pagliacci, M.C.; Grignani, F.; Riccardi, C. A rapid and simple method for measuring thymocyte apoptosis by propidium iodide staining and flow cytometry. J. Immunol. Methods 1991, 139, 271-279. [CrossRef]

23. Rest, R.F. Measurement of human neutrophil respiratory burst activity during phagocytosis of bacteria. Methods Enzymol. 1994, 236, 119-136. [CrossRef] [PubMed]

24. Winterbourn, C.C. The challenges of using fluorescent probes to detect and quantify specific reactive oxygen species in living cells. Biochim. Biophys. Acta 2014, 1840, 730-738. [CrossRef] [PubMed]

25. Kalyanaraman, B.; Darley-Usmar, V.; Davies, K.J.; Dennery, P.A.; Forman, H.J.; Grisham, M.B.; Mann, G.E.; Moore, K.; Roberts, L.J., 2nd; Ischiropoulos, H. Measuring reactive oxygen and nitrogen species with fluorescent probes: Challenges and limitations. Free Radic. Biol. Med. 2012, 52, 1-6. [CrossRef] [PubMed]

26. Rothe, G.; Valet, G. Flow cytometric analysis of respiratory burst activity in phagocytes with hydroethidine and $2^{\prime}, 7^{\prime}$-dichlorofluorescin. J. Leukoc. Biol. 1990, 47, 440-448. [PubMed]

27. Rao, K.M.; Padmanabhan, J.; Kilby, D.L.; Cohen, H.J.; Currie, M.S.; Weinberg, J.B. Flow cytometric analysis of nitric oxide production in human neutrophils using dichlorofluorescein diacetate in the presence of a calmodulin inhibitor. J. Leukoc. Biol. 1992, 51, 496-500. [PubMed]

28. Richter, J.; Ng-Sikorski, J.; Olsson, I.; Andersson, T. Tumor necrosis factor-induced degranulation in adherent human neutrophils is dependent on CD11b/CD18-integrin-triggered oscillations of cytosolic free $\mathrm{Ca}^{2+}$. Proc. Natl. Acad. Sci. USA 1990, 87, 9472-9476. [CrossRef] [PubMed]

29. Scheel-Toellner, D.; Wang, K.; Craddock, R.; Webb, P.R.; McGettrick, H.M.; Assi, L.K.; Parkes, N.; Clough, L.E.; Gulbins, E.; Salmon, M.; et al. Reactive oxygen species limit neutrophil life span by activating death receptor signaling. Blood 2004, 104, 2557-2564. [CrossRef] [PubMed]

30. Cross, A.; Moots, R.J.; Edwards, S.W. The dual effects of TNFalpha on neutrophil apoptosis are mediated via differential effects on expression of Mcl-1 and Bfl-1. Blood 2008, 111, 878-884. [CrossRef] [PubMed]

31. Goldstein, I.M.; Kaplan, H.B.; Edelson, H.S.; Weissmann, G. Ceruloplasmin. A scavenger of superoxide anion radicals. J. Biol. Chem. 1979, 254, 4040-4045. [PubMed] 
32. Mukhopadhyay, C.K.; Fox, P.L. Ceruloplasmin copper induces oxidant damage by a redox process utilizing cell-derived superoxide as reductant. Biochemistry 1998, 37, 14222-14229. [CrossRef] [PubMed]

33. Shukla, N.; Maher, J.; Masters, J.; Angelini, G.D.; Jeremy, J.Y. Does oxidative stress change ceruloplasmin from a protective to a vasculopathic factor? Atherosclerosis 2006, 187, 238-250. [CrossRef] [PubMed]

34. Choi, S.Y.; Kwon, H.Y.; Kwon, O.B.; Eum, W.S.; Kang, J.H. Fragmentation of human ceruloplasmin induced by hydrogen peroxide. Biochimie 2000, 82, 175-180. [CrossRef]

35. Davies, M.J.; Hawkins, C.L.; Pattison, D.I.; Rees, M.D. Mammalian heme peroxidases: From molecular mechanisms to health implications. Antioxid. Redox Signal. 2008, 10, 1199-1234. [CrossRef] [PubMed]

36. Winterbourn, C.C. Biological reactivity and biomarkers of the neutrophil oxidant, hypochlorous acid. Toxicology 2002, 181-182, 223-227. [CrossRef]

37. Freitas, M.; Ribeiro, D.; Tomé, S.M.; Silva, A.M.; Fernandes, E. Synthesis of chlorinated flavonoids with anti-inflammatory and pro-apoptotic activities in human neutrophils. Eur. J. Med. Chem. 2014, 86, 153-164. [CrossRef] [PubMed]

38. Lloyd, M.M.; Grima, M.A.; Rayner, B.S.; Hadfield, K.A.; Davies, M.J.; Hawkins, C.L. Comparative reactivity of the myeloperoxidase-derived oxidants hypochlorous acid and hypothiocyanous acid with human coronary artery endothelial cells. Free Radic. Biol. Med. 2013, 65, 1352-1362. [CrossRef] [PubMed]

39. El Kebir, D.; József, L.; Pan, W.; Filep, J.G. Myeloperoxidase delays neutrophil apoptosis through CD11b/CD18 integrins and prolongs inflammation. Circ. Res. 2008, 103, 352-359. [CrossRef] [PubMed]

40. Lau, D.; Mollnau, H.; Eiserich, J.P.; Freeman, B.A.; Daiber, A.; Gehling, U.M.; Brümmer, J.; Rudolph, V.; Münzel, T.; Heitzer, T.; et al. Myeloperoxidase mediates neutrophil activation by association with CD11b/CD18 integrins. Proc. Natl. Acad. Sci. USA 2005, 102, 431-436. [CrossRef] [PubMed]

41. Grigorieva, D.V.; Gorudko, I.V.; Sokolov, A.V.; Kostevich, V.A.; Vasilyev, V.B.; Cherenkevich, S.N.; Panasenko, O.M. Myeloperoxidase Stimulates Neutrophil Degranulation. Bull. Exp. Biol. Med. 2016, 161, 495-500. [CrossRef] [PubMed]

42. Nathan, C.; Srimal, S.; Farber, C.; Sanchez, E.; Kabbash, L.; Asch, A.; Gailit, J.; Wright, S.D. Cytokine-induced respiratory burst of human neutrophils: Dependence on extracellular matrix proteins and CD11/CD18 integrins. J. Cell Biol. 1989, 109, 1341-1349. [CrossRef] [PubMed]

43. Decleva, E.; Dri, P.; Menegazzi, R.; Busetto, S.; Cramer, R. Evidence that TNF-induced respiratory burst of adherent PMN is mediated by integrin alpha(L)beta(2). J. Leukoc. Biol. 2002, 72, 718-726. [PubMed]

44. Chiewchengchol, D.; Wright, H.L.; Thomas, H.B.; Lam, C.W.; Roberts, K.J.; Hirankarn, N.; Beresford, M.W.; Moots, R.J.; Edwards, S.W. Differential changes in gene expression in human neutrophils following TNF- $\alpha$ stimulation: Up-regulation of anti-apoptotic proteins and down-regulation of proteins involved in death receptor signaling. Immun. Inflamm. Dis. 2015, 4, 35-44. [CrossRef] [PubMed]

45. Salamone, G.; Trevani, A.; Martínez, D.; Vermeulen, M.; Gamberale, R.; Fernández-Calotti, P.; Raiden, S.; Giordano, M.; Geffner, J. Analysis of the mechanisms involved in the stimulation of neutrophil apoptosis by tumour necrosis factor-alpha. Immunology 2004, 113, 355-362. [CrossRef] [PubMed]

46. Test, S.T. Effect of tumor necrosis factor on the generation of chlorinated oxidants by adherent human neutrophils. J. Leukoc. Biol. 1991, 50, 131-139. [PubMed]

47. Chatham, W.W.; Turkiewicz, A.; Blackburn, W.D., Jr. Determinants of neutrophil HOCl generation: Ligand-dependent responses and the role of surface adhesion. J. Leukoc. Biol. 1994, 56, 654-660. [PubMed]

48. Hanlon, W.A.; Stolk, J.; Davies, P.; Humes, J.L.; Mumford, R.; Bonney, R.J. rTNF alpha facilitates human polymorphonuclear leukocyte adherence to fibrinogen matrices with mobilization of specific and tertiary but not azurophilic granule markers. J. Leukoc. Biol. 1991, 50, 43-48. [PubMed]

49. Segelmark, M.; Persson, B.; Hellmark, T.; Wieslander, J. Binding and inhibition of myeloperoxidase (MPO): A major function of ceruloplasmin? Clin. Exp. Immunol. 1997, 108, 167-174. [CrossRef] [PubMed]

50. Karlsson, M.; Kurz, T.; Brunk, U.T.; Nilsson, S.E.; Frennesson, C.I. What does the commonly used DCF test for oxidative stress really show? Biochem. J. 2010, 428, 183-190. [CrossRef] [PubMed]

51. Sokolov, A.V.; Ageeva, K.V.; Pulina, M.O.; Cherkalina, O.S.; Samygina, V.R.; Vlasova, I.I.; Panasenko, O.M.; Zakharova, E.T.; Vasilyev, V.B. Ceruloplasmin and myeloperoxidase in complex affect the enzymatic properties of each other. Free Radic. Res. 2008, 42, 989-998. [CrossRef] [PubMed]

52. Sokolov, A.V.; Ageeva, K.V.; Kostevich, V.A.; Berlov, M.N.; Runova, O.L.; Zakharova, E.T.; Vasilyev, V.B. Study of interaction of ceruloplasmin with serprocidins. Biochemistry 2010, 75, 1361-1367. [CrossRef] [PubMed] 
53. Loison, F.; Zhu, H.; Karatepe, K.; Kasorn, A.; Liu, P.; Ye, K.; Zhou, J.; Cao, S.; Gong, H.; Jenne, D.E.; et al. Proteinase 3-dependent caspase-3 cleavage modulates neutrophil death and inflammation. J. Clin. Investig. 2014, 124, 4445-4458. [CrossRef] [PubMed]

54. Sokolov, A.V.; Solovyov, K.V.; Kostevich, V.A.; Chekanov, A.V.; Pulina, M.O.; Zakharova, E.T.; Shavlovski, M.M.; Panasenko, O.M.; Vasilyev, V.B. Protection of ceruloplasmin by lactoferrin against hydroxyl radicals is pH dependent. Biochem. Cell Biol. 2012, 90, 397-404. [CrossRef] [PubMed]

55. Rydén, L. Evidence for proteolytic fragments in commercial samples of human ceruloplasmin. FEBS Lett. 1971, 18, 321-325. [CrossRef]

56. Kingston, I.B.; Kingston, B.L.; Putnam, F.W. Chemical evidence that proteolytic cleavage causes the heterogeneity present in human ceruloplasmin preparations. Proc. Natl. Acad. Sci. USA 1977, 74, 5377-5381. [CrossRef] [PubMed]

57. Kim, I.G.; Park, S.Y.; Kim, K.C.; Yum, J.J. Thiol-linked peroxidase activity of human ceruloplasmin. FEBS Lett. 1998, 431, 473-475. [CrossRef]

58. Francis, N.; Wong, S.H.; Hampson, P.; Wang, K.; Young, S.P.; Deigner, H.P.; Salmon, M.; Scheel-Toellner, D.; Lord, J.M. Lactoferrin inhibits neutrophil apoptosis via blockade of proximal apoptotic signaling events. Biochim. Biophys. Acta 2011, 1813, 1822-1826. [CrossRef] [PubMed]

59. Sokolov, A.V.; Ageeva, K.V.; Pulina, M.O.; Zakharova, E.T.; Vasilyev, V.B. Effect of lactoferrin on oxidative features of ceruloplasmin. Biometals 2009, 22, 521-529. [CrossRef] [PubMed]

60. Panasenko, O.M.; Gorudko, I.V.; Sokolov, A.V. Hypochlorous acid as a precursor of free radicals in living systems. Biochemistry (Mosc.) 2013, 78, 1466-1489. [CrossRef] [PubMed]

61. Golenkina, E.A.; Livenskyi, A.D.; Viryasova, G.M.; Romanova, Y.M.; Sud'ina, G.F.; Sokolov, A.V. Ceruloplasmin-derived peptide is the strongest regulator of oxidative stress and leukotriene synthesis in neutrophils. Biochem. Cell Biol. 2017, 95, 445-449. [CrossRef] [PubMed]

Sample Availability: Samples of holo-ceruloplasmin, its copper-free (apo-) and partially proteolyzed forms, and synthetic free peptides RPYLKVFNPR (883-892) and RRPYLKVFNPRR (882-893) are available from the authors.

(C) 2018 by the authors. Licensee MDPI, Basel, Switzerland. This article is an open access article distributed under the terms and conditions of the Creative Commons Attribution (CC BY) license (http:/ / creativecommons.org/licenses/by/4.0/). 